\title{
Historical Analysis of African Women Workers in South Africa during the Period 1900 to 2000
}

\section{Pinky Lalthapersad}

Department of Economics, UNISA

\section{ABSTRACT}

The article is a detailed exposition of the history of the incorporation of African women into paid work in the South African labour market. The interlocking effects of racism, classism and sexism exposed African women to income and job insecurity. Historically, access of African women to the labour market was shaped by the gendered nature of the migrant labour system and by legal measures that restricted women's entry into urban areas and waged work. When African women were allowed into the formal labour market, they were only allowed to undertake the low-skilled, low-paying, menial jobs, were excluded from union benefits and forced to work under exploitative conditions.

JEL J16

\section{INTRODUCTION}

This article analyses the passage of entry of African women into paid work. The proletarianisation of African women in South Africa assumed a unique character in that it was forged by the government's policies of institutionalised segregation and inequality.

Any attempt to trace the path of the incorporation of African women into paid work and the anomalies that existed in the labour market must entail an analysis of previous statutory obligations on the utilization of African labour, and the conditions of work itself. African women were trapped in hardship and poverty by a tightly meshed web of restrictions on education, training, housing, work and pay. The subordination of Afric an women was threefold, being premised on race, class and gender. In a highly stratified society and labour market, African women occupied the lowest positions in both arenas.

The experience of African women in South Africa is unique to that of White women within the country, and of women in other countries. Whilst other women could rely on male earnings and were privileged in that they could 
retreat to the household if so desired, African women did not have the luxury of choosing whether or not to work. Their restricted access to urban areas meant that they could not refuse jobs, as they were confronted with a limited range of jobs. Their dire economic circumstances meant that they could not afford to leave work for childbearing or marriage. Women endured the cumulative burden of low wages for themselves and their spouses, male migration, live-in domestic jobs, customary law, traditionalism and state regulation (Berger \& Robertson, 1992: 13).

\section{THE IMPACT OF INFLUX CONTROL ON AFRICAN WOMEN}

Policies of racial segregation in South Africa unleashed a battery of artificial restrictions such as blocked urbanization, influx control and job reservation, which affected the utilization of African labour. The migrant labour system and pass laws served the dual purposes of restricting the movement of people and securing a cheap supply of labour. The exploitative nature of the migrant labour system was such that it forced African women to subsist in the reserves, and prevented them moving to the urban areas, thereby stifling the emergence of an African urban population (Bernstein, 1985: 9). The African women that remained in the reserves fulfilled an important reproductive task in caring for the young, the old and the sick.

Prior to 1950, there were many localized measures aimed at controlling African female urbanization, for example, single female work seekers entering town were housed in labour depots, subject to their finding work. Also, local authorities were given the right to deport women who lacked accommodation. Under Section 10 rights of 1945, African women were allowed into urban areas if they were the wife or unmarried daughters of men who had obtained Section 10 rights (i.e. a person that legally qualified to live in an urban area) (Simons, 1968: 281).

In 1952 a system of influx control applied to both African men and African women. Thus in 1952, the state viewed African women as separate entities within households, who forthwith had to qualify in their own right to be in urban areas. The enactment of the pass laws was an acknowledgment by the state of the collapse of patriarchal control over women (Gwagwa, 1989). Pass laws surfaced at an inopportune time for women, as new avenues of employment were opening up in the formal labour market (Wells, 1993: 8).

In 1959 it was compulsory for women to have their service contracts registered at the pass office. This requirement impinged further on women's access to the formal labour market. Women were placed in a predicament in that even if they 
were able to secure jobs, their service contracts could not be registered if they lacked the appropriate permission from the pass office (Yawitch, 1983: 5). In 1964 the special right of admission granted to wives and daughters was discarded. A wife could be allowed to enter an urban area but could only remain there for no more than 72 hours without permission. Also, in 1964 women had to provide proof of satisfactory accommodation to the labour officer (Yawitch, 1983: 8). This stipulation was grossly vindictive as housing was not available to African women.

The Bantu Labour Regulations Act of 1973, made employers requisition African labour through the bureaux. African workers were not permitted to go to the cities in search of work. The bureaux issued temporary contracts of six to ninemonth's duration. There were seventeen categories of occupations that were open to African males. Only the category of domestic service applied to African women (Kraak, 1993: 10-11). Because registration with the bureaux was voluntary, it disguised the extent of African female unemployment (Yawitch, 1983: 9).

African women who were living lawfully in an urban area could only obtain work through the municipal or district labour officer who was charged with the task of issuing work permits. Labour officers wielded extensive control over women. A permit could be refused for a specific job, women and their dependents could be forced to leave an area or an existing labour contract could be cancelled (Bernstein, 1985: 41).

Women who worked illegally in urban areas endured many hardships. Firstly, they risked being arrested and deported back to the reserves. Secondly, they were exploited by employers who gained by remunerating them low wages. Thirdly, their illegal status meant that they could not challenge low wages or bad working conditions and could be summarily dismissed. Fourthly, they were denied the right to acquire a work profile (Barrett et al., 1985: 13).

The government utilized its policy of influx control to paralyse the entry of African women into urban areas. It weighed more heavily on women than on men, because when women entered the urban areas, they had to contend with low paid jobs of a domestic nature (Walker, 1991: 21).

The migrant labour system produced the rural/urban divide that profoundly affected African woman's future role in the formal labour market. Apartheid legislation resulted in a splintered labour market that afforded different groups, different degrees of security (Standing et al., 1996: 11-13). 


\section{THE EFFECT OF INFLUX CONTROL ON FAMILY RELATIONS AND WORK PATTERNS}

Influx control dislocated family relationships in that African women were denied the right to live with their husbands and lead a normal family life. According to Yawitch (1984: 9) the ultimate effect of Section 10 rights is that it tied African women's urban status to men, and thereby influenced both women's choice of residential abode and their lifestyle. If women divorced, they also risked losing their accommodation.

African women had to contend with a capacious quantity of grossly vindictive laws. 'Offences' such as cohabiting with husbands in employer-provided quarters, or sharing accommodation with men that lacked Section 10 rights, constituted grounds for arrest (Barrett et al, 1985: 19). Domestic workers were also prevented from being transferred with employers (Cock, 1980: 246).

Unemployed African women were especially vulnerable, as they fell within the definition of 'idle Bantu' and could be asked to vacate the area (Cock, 1980: 241). The prospect of being removed from an urban area, coupled with a loss of income was indeed, a very real threat confronting African women.

\section{A BRIEF ANALYSIS OF THE EMPLOYMENT TRENDS OF AFRICAN WOMEN: 1900-1985}

According to Boserup (1970) the 'feminization' of occupations is a corollary of economic development, that is, as economic development occurs, women enter adjacent occupations, causing these new occupations to be 'feminized' (Boserup, 1970: 217). In South Africa, this development assumed a racial character in that, White women moved into jobs that were previously closed to them, like clerical and administrative work, leaving African women to occupy factory jobs (Bernstein, 1985: 69).

The ideology of female domesticity in the labour market was evident in the reservation of appropriate jobs for women. The state by only making the category of domestic work applicable to African women, coerced African women into domestic services (Kraak, 1993: 10-11). Live-in domestic work obliterated any reasonable family life. The slum clearance movement of the 1930s, and the relocation of Africans from the cities to the townships, also made part-time domestic work difficult, and 'washing jobs' impractical due to time and cost factors (Berger, 1980: 134). In this way Afric an women were dealt another blow. 
In 1944, secondary industries experienced rapid growth and underwent increased mechanization, which necessitated a larger skilled workforce. Since 1946 there was a movement of African women away from agriculture and domestic service into industry. The number of African women employed in manufacturing rose from 1 per cent in 1946 to over 20 per cent in 1979 (Bernstein, 1985: 63).

Among the professional occupations, African women flocked into nursing and teaching because they comprised the better-paid options open to African women (Budlender, 1991: 26).

African women dominated service sector jobs which comprised of cleaning office blocks and shops, laundry work, cooking, waitressing, tea and kitchen work and messenger services (Budlender, 1991: 26). In 1980, four sectors, namely, agriculture, manufacturing, commerce and services, employed over 97 per cent of African women workers (Pillay, 1985: 23). In 1981, nine times as many women as men were employed in service jobs (Kraak, 1993: 84). In 1985, African women made up 88 per cent of domestic workers, cleaners or chars. Thus, the South African labour market was stratified in terms of both sex and race.

\section{Women, employment and conditions at work}

Working conditions confronting African women in industry was usually harsh and inflexible. Time was so tightly regulated that a timekeeper was usually employed to check on the time women reported, in and the time spent away from their work stations (Bernstein, 1985: 69). In some industries women were expected to clock in and out when availing themselves of the bathroom (Berger \& Robertson, 1986: 222).

In many instances African women also worked in employers' kitchens, performing domestic chores. They were employed in labour-intensive sectors, where work was strenuous and involved standing for long hours. Whilst White women were excluded from heavy, physical work, African women were the only group of women that undertook such jobs (Berger, 1992: 70).

Women worked in conditions that posed a hazard to their health. Expectant mothers worked in refrigeration rooms and endured ailments such as rheumatism and arthritis (Mashinini, 1989: 115). Women employed in bakeries had to endure extreme heat and the associated negative health problems in terms of high blood pressure, skin diseases and dizziness (Gwagwa, 1989). 
African women had to contend with severe authoritianism. In some circumstances, pay was deducted for arriving late at work, even though the dismal transport system was to blame. Women could also be fired for missing a day of work. Complaining of low pay or demanding better wages, carried the risk of dismissal and a ultimate loss of income. Another trend was to replace women in their late thirties and forties with younger women, claiming they were too old to work. Many African women were forced to accept temporary employment, thereby forfeiting benefits and the ability to acquire an employment history and service card (Yawitch, 1984: 24).

Supervisors checked for signs of pregnancy. In one engineering factory in 1920, African women were forced to take the contraceptive pill, under nurses' supervision. In some companies, factory doctors were instructed to watch for signs of pregnancy (Berger, 1992: 226). To keep their jobs, women attempted to prevent and conceal pregnancy at all costs (Barrett et al., 1985: 143).

There were other petty and humiliating regulations in the textile and clothing industries. Company policy restricted the excessive use of toilet paper. Searching of African women in some stores and workplaces meant that African women employees were stripped naked, even during menstruation. Possession of trade union material found during these searches, were grounds for dismissal (Mashinini, 1989: 113). Also, in the textile and garment industry, management utilized patriarchal principles to obtain control and discipline over workers. Male supervisors were able to dispense permission to go to the bathroom or take a rest in exchange for sexual favours from workers (Berger \& Robertson, 1986: 229). In the clothing factories, there was a readiness to fire women without prior notification and it was not unusual for ten people to be dismissed in the course of a day (Budlender, 1991: 18 -21).

At most firms workers were offered no tea or coffee and were only allowed a ten minute tea break. Time constraints meant that lunch had to be hastily consumed, sparing little time for relaxation (Mashinini, 1989: 6).

Industrial work often carried the penalty of a postponement of childbirth. In the Industrial Council agreement of 1983 covering sick leave, no provision was made for maternity leave for female workers, nor special sick leave in the case of women who suffered miscarriages. The majority of African women workers were forced to work until the final stages of pregnancy. Many women received no maternity benefits at all. Although the Industrial Council Agreement of 1983 stipulated twelve weeks maternity leave, it did not compel employers to hold the job for returnees. If on the other hand women were re- hired, their maternity leave constituted broken service and workers received a drop in salary (Bernstein, 1985: 70). 
From 1970 onwards, textile industries in Durban resorted to hiring African female migrants rather locals as migrants tended to work for lower wages. Female migrants were housed in single-sex hostels and had to sleep two to a bed. Women were limited to the confines of the hostel which was fenced in, and permanently guarded. They were subject to many petty rules which included expulsion for refusing to pick litter, being forbidden from smoking and drinking in rooms, and bringing children into rooms. Controls were imposed on women even during their free time (Berger \& Robertson, 1986: 230).

Mashinini points out that the association of white skin with preferential treatment in the labour market was so well established, that African women resorted to using skin lighteners in the hope of inducing favourable treatment (Mashinini, 1989: 8).

In jobs involving night work, women worked eight hour shifts each night, cleaning office blocks, shops and supermarkets. Women employed in the textile industries in the border region worked night shifts. Shifts were twelve hours long and lasted seven days a week, with two shifts off per fortnight. Most spinners and weavers spent the entire shift on their feet (Mashinini, 1989: 57).

Many African women employed in factories in menial work were excluded from the grading system. Such exclusion separated women from the rest of the workforce and deprived them of union gains (Mashinini, 1989: 84).

\section{The African Female Labour Force in the 1990s}

In 1991, the occupational structure of the South African female labour force displayed three glaring disparities in terms of the distribution of African workers. Firstly, African women comprised a negligible portion of managerial and administrative staff ( 2.5 per cent) compared to women of other racial groups (20 per cent). Secondly, there was a high proportion of women in service occupations (namely, 34 per cent). Thirdly, 46 per cent of African women practised occupations that were classified as 'unspecified'. The large numbers of African women workers comprising the 'unspecified' category points to their preponderance to undertake work in the informal sector. Furthermore, African women constituted the lowest percentage of professional and technical workers (6 per cent) compared to women of other race groups (52 per cent). They also comprised a mere 1 per cent of artisans (SSA, 1993).

A more recent account of the occupational stratification is shown in tables 1 and 2 which are based on the October Household Survey for 1995, 1997, 1998 and 1999. Although the data is not comparable across the years due to differences in 
sample sizes, they do convey succinct details on the employment trends of African women.

According to Table 1, African women comprised two-thirds of the total female workers and White women a fifth of the total. A common pattern across all five years is the fact that African women predominate in five industries, namely, agriculture, manufacturing, wholesale trade, community and social services and private households. A peculiar feature of these industries is that they tend to be low-paying, are typically involved in women's work, possess unpleasant working conditions and few fringe benefits. There are also very few White women in these industries. Whilst White women consistently make up more than 50per cent of those in finance and insurance, African women are sparsely located in this industry, an industry that actually contains more lucrative jobs.

Table 1 Distribution of African and White female workers per industry

\begin{tabular}{|c|c|c|c|c|c|c|c|c|}
\hline \multirow[t]{2}{*}{ Industry } & \multicolumn{2}{|c|}{1995} & \multicolumn{2}{|c|}{1997} & \multicolumn{2}{|c|}{1998} & \multicolumn{2}{|c|}{1999} \\
\hline & $\% \mathrm{AF}$ & $\% \mathrm{WF}$ & $\% \mathrm{AF}$ & $\% \mathrm{WF}$ & $\% \mathrm{AF}$ & $\% \mathrm{WF}$ & $\% \mathrm{AF}$ & $\% \mathrm{WF}$ \\
\hline $\begin{array}{l}\text { Total female } \\
\text { workers }\end{array}$ & 60 & 39 & 62 & 21 & 61 & 22 & 63 & 20 \\
\hline Agriculture & 71 & 6 & 63 & 5 & 76 & na & 76 & 5 \\
\hline Manufacturing & 54 & 17 & 55 & 17 & 54 & 19 & 55 & 16 \\
\hline Wholesale trade & 55 & 27 & 64 & 18 & 64 & 19 & 65 & 18 \\
\hline Transport & 45 & 62 & 38 & 44 & 30 & 57 & 39 & 45 \\
\hline $\begin{array}{l}\text { Finance \& } \\
\text { insurance }\end{array}$ & 21 & 66 & 25 & 55 & 27 & 56 & 29 & 54 \\
\hline $\begin{array}{l}\text { Community \& } \\
\text { social }\end{array}$ & 71 & 17 & 57 & 29 & 57 & 28 & 59 & 27 \\
\hline $\begin{array}{l}\text { Private } \\
\text { households }\end{array}$ & na & na & 89 & 1 & 85 & 1 & 87 & na \\
\hline
\end{tabular}

Own analysis based on 1995, 1997, 1998 \& 1999 OHS: SSA

Table 2 highlights the skewed distribution of African and White women workers occupationally. African women were in the main located in the following occupational categories, namely:

- technicians;

- $\quad$ service workers;

- $\quad$ skilled agriculture;

- $\quad$ craft workers; 
- $\quad$ plant operators;

- $\quad$ elementary occupations; and

- domestic work.

Also evident from Table 2 is the fact that White women featured prominently in the following categories, namely:

- legislators;

- $\quad$ professionals; and

- clerks.

The occupations into which African women are clustered in are essentially secondary sector jobs which offer very little training and avenues for mobility. Furthermore, they are either peripheral activities in a job or an extension of women's caring responsibilities. The occupations that White women dominate can be classified as better-paying, more challenging, occupations that offer opportunity for advancement, acceptable wages and have pleasant working conditions.

The above analysis reflects the nature of the South African labour market where African women workers are crowded into certain occupations and industries. A palpable reason for this clustering is due to low levels of human capital and lack of formal labour market experience, a factor that is both reinforcing and limiting. It distinctly reflects the unique labour market status of African women workers who are disadvantaged by both income and work insecurity. They have little chance of securing a regular job that is adequately paying. African women are highly marginalized in the labour market as they are the least likely of all workers to be in formal employment. When employed they tend to be located in jobs that are poorly paid and exploitative, such as domestic work and informal sector work. The proportion of African women undertaking elementary occupations is indicative of the monopolization of African women of informal sector work. Informal sector work mostly entails survivalist activities that pay a low income that is very erratic.

An intricate aspect of labour markets, is joblessness and African woman, bore the brunt of unemployment. African women have the highest rate of unemployment which makes them the most vulnerable of all groups in South Africa. In 1993 over 70 per cent of African women aged between 16 to 24 were unemployed according to the expanded definition (that is, job search excluded). In 1997 the unemployment rate for African women was 34.6 per cent according to the official definition and over 50 per cent based on the expanded definition (SSA: 1998). 
Table 2 Distribution of African and White female workers per occupation

\begin{tabular}{||l|c|c|c|c|c|c|c|c||}
\hline \multicolumn{1}{|c|}{ Occupation } & \multicolumn{2}{|c|}{1995} & \multicolumn{2}{c|}{1997} & \multicolumn{2}{c|}{1998} & \multicolumn{2}{c||}{1999} \\
\hline & $\% \mathrm{AF}$ & $\% \mathrm{WF}$ & $\% \mathrm{AF}$ & $\% \mathrm{WF}$ & $\% \mathrm{AF}$ & $\% \mathrm{WF}$ & $\% \mathrm{AF}$ & $\% \mathrm{WF}$ \\
\hline $\begin{array}{l}\text { Total female } \\
\text { workers }\end{array}$ & 60 & 39 & 62 & 21 & 61 & 22 & 63 & 20 \\
\hline Legislators & 35 & 56 & 32 & 51 & 32 & 51 & 23 & 62 \\
\hline Professionals & 42 & 47 & 54 & 32 & 34 & 50 & 38 & 51 \\
\hline Technicians & 58 & 32 & 46 & 38 & 51 & 33 & 57 & 30 \\
\hline Clerks & 30 & 54 & 34 & 44 & 30 & 49 & 35 & 43 \\
\hline Service workers & 58 & 21 & 61 & 19 & 69 & 17 & 62 & 19 \\
\hline $\begin{array}{l}\text { Skilled } \\
\text { agriculture }\end{array}$ & 55 & 33 & 79 & na & 94 & na & 83 & 5 \\
\hline Craft workers & 63 & 16 & 68 & 9 & 75 & 9 & 71 & 13 \\
\hline Plant operators & 61 & 4 & 60 & na & 54 & 8 & 58 & 6 \\
\hline Elementary & 83 & 0 & 75 & 3 & 81 & na & 82 & 2 \\
\hline Domestic & na & na & 89 & 1 & 88 & na & 87 & 0 \\
\hline \hline
\end{tabular}

Own analysis based on 1995, 1997, 1998 \& 1999 OHS: SSA

\section{CONCLUSION}

The state exerted rigorous control over the lives of African families. Laws governed the physical movement of African people, access to the cities, the right to housing and above all, access to the job market. The Pass Laws of the 1950s severely restricted the movement of African women. The migration of women to towns was dictated by employer needs rather than family considerations. When African women did come to the urban areas, they faced a number of constraints on their employment and occupational choice, that is, a rigid sexual and racial stereotyping, which excluded them from jobs in the formal industrial sector. They were targeted for domestic work and even when allowed into formal industry, were given the menial and lowest paid jobs.

In many industries, African women worked under hazardous and unhealthy conditions. Their private lives were controlled by employers who, handed contraceptives, monitored signs of pregnancy and summarily dismissed workers. African women spent long, tedious hours travelling to work, earning salaries 
that were extremely low, with the threat of job loss and removal from urban areas, ever present.

The South African labour market has inherited structural rigidities and inequalities from the apartheid era. African women were found only in a few industries and occupations. African women's marginality in the South African labour market is evident in the kinds of jobs they undertake, that is, there is a very small number of them in managerial positions.

African women have to be provided with education and training to enable them to filter into higher-paying jobs and become more representative in the formal labour market. Business and government have to make a concerted effort to this end. Trade unions have begun to address the issue of casualisation of work in the loom of globalisation that is beginning to grip the South African economy. In this regard, three key pieces of legislation that have been introduced are crucial. Firstly, the Employees Standards Act of 1999 is a measure that aims to protect full-time, part-time and contract workers. Such a measure will offer employment and work security to these groups that tend to be overwhelmingly female. Secondly, the Employment Equity Act of 1998 seeks to remove unfair discrimination in hiring, promotion, training, pay benefits and retrenchments. It will amongst other things, compel employers to accommodate the needs of women and disabled people and achieve a more representative workforce. Thirdly, the Skills Development Act of 1998 which seeks to equip workers with skills to enable them to improve their quality of life, employability and productivity. Such process bodes well for the future, especially if women are to make a meaningful contribution to the economy.

\section{REFERENCES}

1 BARRETT, J., DAWBAR, A., KLUGMAN, B., OBERY, I., SCHINDLER, J. \& YAWITCH, J. (1985) Vukani Makhosikazi: South African Women Speak, London : Catholic Institute for International Relations.

2 BERGER, I. \& ROBERTSON, C. (1986) Women and Class in Africa. New York: Africana Publishing Company.

3 BERGER, I. (1992) Threads of Solidarity - Women in SA Industry 19001980, Indianapolis: Indiana University Press.

4 BERNSTEIN, H. (1985) For Their Triumphs and for Their Tears: Women in Apartheid South Africa. London: International Defence and Aid Fund for Southern Africa.

5 BOSERUP, E. (1970) Women's Role in Economic Development, New York: St Martin's Press. 
6 BUDLENDER, D. (1991) Women and the Economy, Johannesburg: Case Offices.

7 COBBETT, W. \& NAKEDI, B. (1987) "Behind the 'curtain' at Botshabelo: Redefining the urban labour market in South Africa", Review of African Political Economy, 40: 32-46.

8 COCK, J. (1980) Maids and Madams - A Study in the Politics of Exploitation, Johannesburg: Ravan Press.

9 GWAGWA, N.N. (1989) "The family and women's emancipation in South Africa", Paper read at the Malibongwe Conference, Amsterdam.

10 KRAAK, G. (1993) Breaking the Chains - Labour in South Africa in the 1970s and 1980s, London: Pluto Press.

11 KUZWAYO, E. (1960) "The role of the African women in towns", Journal of the South African Institute of Race Relations, 22: 40-48.

12 MAGER, A. (1989) 'Moving the fence: gender in the Ciskei and border textile industry, 1945-1986", Social Dynamics, 15(2): 46-62.

13 MASHININI, E. (1989) Strikes Have Followed Me All My Life: A South African Autobiography, London: The Women's Press.

14 PILLAY, P. (1985) "Women in employment in South Africa: some important trends and issues", Social Dynamics, 11(12): 203-37.

15 STANDING, G., SENDER, J. \& WEEKS, J. (1996) Restructuring the South African Labour Market: The South African Challenge, Geneva:ILO Office.

16 SIMONS, H.J. (1968) African Women: Their Legal Status in South Africa, United Kingdom: Northwestern University Press.

17 Statistics South Africa (SSA) (1996) Census in Brief, Pretoria.

18 SSA (1993) South African Labour Statistics, Pretoria.

19 SSA (1995) October Household Survey, Pretoria.

20 SSA (1997) October Household Survey, Pretoria.

21 SSA (1998) October Houshold Survey, Pretoria.

22 SSA (1999) October Household Survey, Pretoria.

23 VAN ONSELEN, C. (1982) Studies in the Social and Economic History of the Witwatersrand 1886-1914. Vol 1. Johannesburg: Ravan Press.

24 WALKER, J.C. (1991) Women and Resistance in South Africa: Cape Town: David Philip.

25 WELLS, J.C. (1993) We Now Demand - A History of Women's Resistance to the Pass Laws in South Africa, Johannesburg: Wits University Press.

26 YAWITCH, J. (1983) "The incorporation of African women into wage labour 1950-1980", South African Labour Bulletin 9(3): 10-24.

27 YAWITCH, J. (1984) "Tightening the noose: African women and influx control in South Africa 1950-1980", Carnegie conference Paper no 82. Second Carnegie Inquiry into Poverty and Development in South Africa. Cape Town. 